\title{
Preventive treatment in migraine and the new US guidelines
}

\author{
This article was published in the following Dove Press journal: \\ Neuropsychiatric Disease and Treatment \\ 16 May 2013 \\ Number of times this article has been viewed
}

\section{E Estemalik \\ S Tepper}

Cleveland Clinic, Neurological Center for Pain, Cleveland, Ohio, USA
Correspondence: Emad Estemalik Cleveland Clinic, Neurological Center for Pain, 9500 Euclid Avenue, Cleveland, Ohio, USA

Tel +l 2166365549

Fax + I 2164451696

Email estemae@ccf.org
Abstract: Migraine headaches are among the most common headache disorders seen in various practices. The prevalence of migraine headaches is $18 \%$ in women and $6 \%$ in men. While millions of Americans suffer from migraine headaches, roughly $3 \%-13 \%$ of identified migraine patients are on preventive therapy, while an estimated $38 \%$ actually need a preventive agent. The challenge among physicians is not only when to start a daily preventive agent but which preventive agent to choose. Circumstances warranting prevention have been described in the past, and in 2012, a new set of guidelines with an evidence review on preventive medications was published. A second set of guidelines provided evidence on nonsteroidal anti-inflammatory drugs, herbs, minerals, and vitamins for prevention of episodic migraine. This article describes the updated US guidelines for the prevention of migraines and also outlines the major studies from which these guidelines were derived.

Keywords: US guidelines, Canadian guidelines, classification, preventive medication

\section{Introduction}

Headaches are among the most common disorders seen by both neurologists and primary care physicians. The classification of these disorders is included in the International Classification of Headache Disorders, second edition, published in $2004 .{ }^{1}$ Headaches are classified into primary and secondary types. Migraines and tension-type headaches are the most common of the primary headache disorders. Migraine disorders are further classified into migraine without aura, migraine with aura, familial or sporadic hemiplegic migraine, and basilar-type migraine. Complications of migraines include chronic migraine, status migrainosus, persistent aura without infarction, migrainous infarction, and migraine-triggered seizures. The prevalence of migraine headaches is higher in women (18\%) than in men $(6 \%){ }^{2}$

Migraine attacks often trigger impairment and lack of ability to function. Migraineurs often isolate themselves in a quiet and dark area. The financial burden is also enormous. Annual health care utilization may exceed one billion dollars for migraine patients while loss of productivity for employers may reach billions of dollars. ${ }^{3}$ While millions of Americans suffer from migraines, roughly $3 \%-13 \%$ are on preventive therapy, while an estimated $38 \%$ actually need a preventive agent. ${ }^{4}$

\section{Some migraine subtypes}

The International Classification of Headache Disorders, second edition outlines the following criteria for some of the migraine types: migraine without aura, migraine with aura, and complicated migraine. ${ }^{1}$ 


\section{Migraine without aura}

1. At least five attacks fulfilling criteria 2-4.

2. Headache attacks lasting 4-72 hours (untreated or successfully treated).

3. Headache has at least two of the following characteristics: unilateral location; pulsating quality; moderate or severe pain intensity; aggravation by or causing avoidance of routine physical activity (eg, walking or climbing stairs).

4. During headache at least one of the following: nausea and/or vomiting; photophobia and/or phonophobia.

5. Not attributed to another disorder.

\section{Migraine with aura}

\section{Basilar-type migraine}

1. At least two attacks fulfilling criteria 2-4.

2. Aura consisting of at least two of the following fully reversible symptoms, but no motor weakness: dysarthria; vertigo; tinnitus; hypacusia; diplopia; visual symptoms simultaneously in both temporal and nasal fields of bilateral eyes; ataxia; diminished level of consciousness; simultaneously bilateral paresthesias.

3. At least one of the following: at least one aura develops gradually over $\geq 5$ minutes and/or different aura symptoms occur in succession over $\geq 5$ minutes; each aura symptom lasts $\geq 5$ minutes to $\leq 60$ minutes.

4. Migraine without aura begins during the aura or follows aura within 1 hour.

5. Not attributed to another disorder.

\section{Sporadic hemiplegic migraine}

1. At least two attacks fulfilling criteria 2 and 3.

2. Aura consisting of fully reversible motor weakness and at least one of the following: fully reversible visual symptoms including positive features (eg, flickering lights, spots or lines) and/or negative features (eg, loss of vision); fully reversible sensory symptoms including positive features (eg, pins and needles) and/or negative symptoms (eg, numbness); fully reversible dysphasic speech disturbance.

3. At least two of the following: at least one aura symptom develops gradually over $\geq 5$ minutes and/or different aura symptoms occur in succession over $\geq 5$ minutes; each aura symptom lasts $\geq 5$ minutes to $\leq 24$ hours; migraine without aura begins during the aura or follows onset of aura within 1 hour.

4. No first- or second-degree relative has attacks fulfilling criteria 1-5.

5. Not attributed to another disorder.

\section{Complicated migraine}

Chronic migraine ${ }^{5}$

1. Headache $\geq 15$ days per month for $\geq 3$ months.

2. Occurring in a patient who has at least five attacks of migraine without aura.

3. Headache $\geq 8$ days per month for $\geq 3$ months: criteria for migraine without aura are met and/or the headache is treated and relieved by triptan(s) or ergot.

4. There is no medication overuse or secondary cause.

\section{Pathophysiology of migraine}

Migraine is usually a hereditary disorder, and the genesis of an attack is associated with neuronal activation. The site of initiation of attacks remains debatable. Two current concepts of migraine genesis are via cortical spreading depression (CSD) or a brainstem generator.

CSD is the basis of migraine aura. It consists of cortical neuronal activation, followed by a postictal depression of neuronal firing. CSD can trigger meningeal pain mechanisms through neurogenic inflammation, vasodilatation, and plasma protein extravasation.

As noted, CSD consists of a slow activation of neurons and glia accompanied by hyperemia, implying spreading activation. Precipitating factors include trauma, embolus, chemical exposure, or electrical activity. ${ }^{6,7}$

This initial wave activation is followed by a wave of decreased brain activity and oligemia. The wave of activation and then depression spreads at a rate of $3 \mathrm{~mm} /$ minute and occurs in various areas of the brain including the cerebellum, cortex, or hippocampus. CSD further alters the blood-brain barrier by activating brain matrix metalloproteinases, which open the blood-brain barrier and may contribute to migraine pain. ${ }^{6}$

Also related to CSD is the activation of cortical glutamatergic synapses. Subsequent to the initiation of a migraine by either CSD or a brain stem generator, meningeal pain mechanisms commence through trigeminovascular activation. These mechanisms include the release of inflammatory cytokines, neuroinflammatory peptides, and calcitonin gene-related peptide, the latter being responsible for cerebral vasodilatation. The vasodilatation and neurogenic inflammation sensitize trigeminovascular sensory fibers that in turn carry pain signals via the trigeminal ganglion to the trigeminal nucleus caudalis. ${ }^{8}$ Activation of these peripheral nociceptors is referred to as peripheral sensitization. Activation of the trigeminal nucleus caudalis and rostral brain structures is referred to as central sensitization. ${ }^{9}$ 


\section{Clinical circumstances prompting pharmacologic preventive treatment}

Pharmacological interventions in the treatment of migraine headaches include acute therapy, with the goal of terminating and aborting attacks, and daily preventive therapy.

The 2000 US Headache Consortium defined the following goals for preventive treatment: (1) decrease attack frequency by $50 \%$ and decrease intensity and duration; (2) improve responsiveness to acute therapy; (3) improve function and decrease disability; and (4) prevent the occurrence of a medication overuse headache (MOH) and chronic daily headache. ${ }^{10}$

Prevention should not be limited to pharmacological treatment. Nonpharmacological approaches may include cognitive behavioral therapy, relaxation techniques, and biofeedback. The following consensus outlines circumstances for daily pharmacological treatment: ${ }^{11}$

"migraine interfering with daily routine despite acute treatment; failure, contraindication to, or side effects from acute medications; circumstances as hemiplegic migraine; more than two headaches a week; or [increasing risk of transformation to daily headache] or patient preference." 10

The American Migraine Prevalance and Prevention Study outlined recommendations as to when daily pharmacological treatment should be initiated:

1. Prevention should be initiated: at least six headache days per month; at least four headache days with at least some impairment; at least three headache days with severe impairment or requiring bed rest.

2. Prevention should be considered with: four to five migraine days per month with normal functioning; two to three migraine days per month with some impairment; two migraine days with severe impairment.

3. Prevention is not indicated with: less than four headache days per month and no impairment; zero or one headache day per month regardless of impairment. ${ }^{3}$

Silberstein et al recommended the following steps for optimal prevention:

1. Start at a low dose.

2. Give each preventive medication an adequate trial, $\geq 2$ months.

3. Avoid interfering, contraindicated, or overused medications.

4. Reevaluate therapy; follow-up is important.
5. Discuss contraception with women in childbearing age and the potential risk of medication with pregnancy.

6. Involve patients in their care to improve adherence.

7. Consider comorbid problems, and choose one medication to treat multiple comorbid disorders where possible.

8. Choose a drug based on efficacy, patient's preferences, headache profile, the drug's side effects, and the presence or absence of coexisting or comorbid conditions..$^{11,12}$

The frequency of headache days and increased use of acute medications per month are both related to the development of $\mathrm{MOH}$ and transformation of episodic migraine to chronic migraine. Since $\mathrm{MOH}$ is more refractory and more disabling than episodic migraine, intervening with preventive medications in patients at risk is warranted. Patients with already established $\mathrm{MOH}$ require a weaning or detoxification during the initiation of preventive treatment, or the treatment will often fail. Most acute medications taken over 10 days per month is a sufficient frequency for patients to develop $\mathrm{MOH}$, but butalbital can cause $\mathrm{MOH}$ when used more than once weekly and opioids more than 8 days per month. ${ }^{13}$

\section{Mechanisms of action of preventive therapies}

Many medications are used in migraine prevention, although currently in the US, not one of these was developed specifically for migraine. These include antiepileptic drugs, beta and calcium channel blockers, several subtypes of antidepressants, some other antihypertensives, miscellaneous medications, and supplements, herbs, and vitamins. Preventive medication mechanism of action includes inhibiting CSD through a variety of mechanisms. These include blocking calcium and sodium channels, inhibition of matrix metalloproteinases, blocking gap junctions, and correcting mitochondrial myopathy.

In a study of animal models, CSD was induced to evaluate various medications currently used for migraine prevention. ${ }^{14}$ The investigators illustrated that the migraine preventive medications tested elevated the CSD threshold and caused suppression of CSD. ${ }^{14}$

Some preventive medications also have antiadrenergic effects and serotonin (5HT) modulatory effects, thereby causing a net inhibition on central neuronal hyperexcitability. They may further enhance the effect of the neurotransmitter gamma-aminobutyric acid (GABA), thus increasing the inhibitory tone leading to a decrease in neuronal firing. ${ }^{15-17}$

Tricyclic antidepressants differ by type, but all inhibit norepinephrine and 5HT high affinity uptake. They 
further downregulate beta-adrenergic receptors, leading to a decrease in neuronal excitatory tone. ${ }^{15}$ The prevention of neurogenic inflammation may be mediated by a blockade of 5HT receptors and inhibition of arachidonic acid metabolism at the onset of a migraine attack. ${ }^{16}$ In addition, tricyclic antidepressants also upregulate GABA-B receptors. Calcium channel blockers suppress CSD by inhibiting calcium influx, reducing glutamate release, and inhibiting 5HT release. ${ }^{17}$

Beta blockers possibly exert their effects by reducing adrenergic tone overall through a variety of actions. These include presynaptic noradrenergic receptor blockade, reducing norepinephrine release and synthesis, inhibiting central beta-adrenergic receptors, and reducing the activity at the level of the adrenergic locus ceruleus. ${ }^{18}$

The effects of angiotensin-converting enzyme inhibitors and angiotensin receptor blockers on migraine prevention remain unclear. Angiotensin II modulates both potassium channels and calcium activity, increasing 5HT turnover, and thereby increasing the metabolite 5-hydroxyindoleacetic acid. ${ }^{19}$

There are several antiepileptic drugs used in the prevention of migraines. Gabapentin blocks voltage-gated calcium channels and increases GABA concentration through an increase in GABA synthesis. This in return may increase 5HT concentration with further inhibitory actions. ${ }^{20}$ The effectiveness of gabapentin and its derivative pregabalin in migraine prevention is not established clearly by randomized controlled trials (RCTs).

Topiramate blocks both calcium and sodium channels, inhibits excitatory glutamatergic receptors, and enhances GABA inhibitory activity. ${ }^{21}$ Additionally, topiramate inhibits central activation of the trigeminal nucleus caudalis and upper spinal cord.

The mechanism of valproate is likely through increasing brain GABA, thus suppressing neurogenic inflammation via GABA-A receptors and directly attenuating nociceptive neurotransmission. The agent further enhances GABA synthesis, inhibits GABA degradation, and increases responsiveness to GABA. ${ }^{22}$ It also modulates $5 \mathrm{HT}$, therefore suppressing the rostral brain stem modulator. CSD is presumably also suppressed by the reduction in overall glutamate activity. ${ }^{23}$

Vitamins, minerals, and herbs are also utilized in the prevention of migraines. Low magnesium is associated with increased glutamate activation and CSD. ${ }^{24,25}$ Magnesium serves as a plug in the N-methyl-D-aspartic acid glutamate receptor, thus magnesium blocks glutamate receptors.
Petasites, a derivative of the butterbur root, blocks leukotriene synthesis. Leukotrienes are released in migrainous inflammation. ${ }^{26}$

Mitochondrial dysfunction may also play a role in migraine pathogenesis, due to reported inadequate phosphorylation of adenosine diphosphate to adenosine triphosphate. Large doses of both vitamin B2 and coenzyme Q10 (CoQ10) may augment activity of mitochondrial complexes and are therefore used in migraine prevention. ${ }^{27,28}$

\section{Evidence of effectiveness}

The US Headache Consortium published the first guidelines and technical reports on preventive medications for episodic migraine in 2000. ${ }^{10,29}$ Since then, new clinical studies have been published assessing the safety and efficacy of additional preventive medications in migraines, but unfortunately, the total number of new studies has been few. For example, there have been no additional studies published on acebutolol, atenolol, carbamazepine, clonazepam, clonidine, clomipramine, fluvoxamine, nabumetone, nadolol, nicardipine, nifedipine, or protriptyline. In 2012, a new set of guidelines with an evidence review on preventive medications was published. ${ }^{30} \mathrm{~A}$ second set of guidelines provided evidence on nonsteroidal anti-inflammatory drugs (NSAIDs), herbs, minerals, and vitamins for prevention of episodic migraine. ${ }^{31}$ The 2012 guidelines used the following criteria:

1. Class I studies were RCTs with masked or objective outcome assessment(s). Baseline characteristics had to be substantially equivalent among treatment groups or appropriate statistical adjustments were made for differences. There had to be concealed allocation, primary outcome(s) and exclusion/inclusion had to be clearly defined, there had to be adequate accounting for dropouts ( $\geq 80 \%$ enrolled subjects completing), and there had to be explicitly defined thresholds for equivalence or noninferiority. Class I studies had to use standard treatments, inclusion/exclusion criteria, and outcomes used had to be similar to those previously used. Study interpretation per protocol analysis had to take into account dropouts or crossovers.

2. Class II studies were RCTs with masked/objective outcome assessments lacking one criterion for a Class I study.

3. Class III studies were other controlled trials (eg, natural history controls or patients are their own controls) with outcomes independently assessed by objective outcomes.

4. Class IV studies were studies not meeting Class I, II, or III criteria including consensus or expert opinion. ${ }^{30}$ 
The ratings in the 2012 guidelines were as follows:

1. Level A: established efficacy (at least two Class I trials).

2. Level B: probably effective (one Class I or at least two Class II studies).

3. Level C: possibly effective (at least one Class II study).

4. Level $\mathrm{U}$ : inadequate or conflicting data to support or refute use.

5. Other: treatments that are established as possibly or probably ineffective. ${ }^{30}$

\section{Preventive medications for migraine: update Antiepileptic drugs}

The main migraine preventive drugs studied in this category included divalproex and sodium valproate, gabapentin, lamotrigine, oxcarbazepine, and topiramate. Within the
2012 guidelines, the only antiepileptic drugs with established efficacy in migraine prevention were divalproex sodium/ sodium valproate and topiramate. The data on gabapentin remain insufficient to determine effectiveness. Lamotrigine was established as probably ineffective in migraine prevention, while oxcarbazepine is possibly ineffective.

\section{Topiramate}

There have been eleven studies since the 2000 guidelines reporting efficacy of topiramate in migraine prevention. ${ }^{32-34}$ One Class I placebo-controlled study showed a lower 28-day frequency of migraine headaches versus placebo (3.31 versus 3.81 ). In the regulatory trials, $100 \mathrm{mg}$ was the optimal dose for prevention. ${ }^{35,36}$

Two Class I studies also reported topiramate to be as effective as propranolol ${ }^{33}$ and sodium valproate. ${ }^{37}$ In the first study, there was a monthly decrease of headache frequency, duration, and

Table I Classification of migraine preventive therapies available in the US

\begin{tabular}{|c|c|c|c|c|}
\hline $\begin{array}{l}\text { Level A: medications } \\
\text { with established efficacy } \\
\text { (at least class I trials) }\end{array}$ & $\begin{array}{l}\text { Level B: medications } \\
\text { are probably effective } \\
\text { (one class I or at least } \\
\text { two class II studies) }\end{array}$ & $\begin{array}{l}\text { Level C: medications } \\
\text { are possibly effective } \\
\text { (one class II study) }\end{array}$ & $\begin{array}{l}\text { Level U: inadequate } \\
\text { or conflicting data } \\
\text { to support or refute } \\
\text { medication use }\end{array}$ & $\begin{array}{l}\text { Other: medications } \\
\text { that are established } \\
\text { as possibly or } \\
\text { probably ineffective }\end{array}$ \\
\hline Antiepileptic drugs ${ }^{\mathrm{a}}$ & $\begin{array}{l}\text { Antidepressants/ } \\
\text { SSRI/SSNRI/TCA }\end{array}$ & $\begin{array}{l}\text { ACE inhibitors } \\
\text { Lisinopril }\end{array}$ & $\begin{array}{l}\text { Carbonic anhydrase } \\
\text { inhibitor }\end{array}$ & $\begin{array}{l}\text { Established as not } \\
\text { effective }\end{array}$ \\
\hline Divalproex sodium & Amitriptyline & $\begin{array}{l}\text { Angiotensin } \\
\text { receptor blockers }\end{array}$ & Acetazolamide & Antiepileptic drugs \\
\hline Sodium valproate & Venlafaxine & Candesartan & Antithrombotics & Lamotrigine \\
\hline Topiramate & Beta blockers & Alpha-agonists & Acenocoumarol & Probably not effective \\
\hline Beta blockers & Atenolol $^{\mathrm{a}}$ & Clonidine $^{\mathrm{a}}$ & Coumadin & Clomipramine $^{\mathrm{a}}$ \\
\hline \multicolumn{5}{|l|}{ Metoprolol } \\
\hline \multicolumn{5}{|l|}{ Propranolol } \\
\hline Timolol $^{\mathrm{a}}$ & Nadolol $^{\mathrm{a}}$ & Guanfacine $^{a}$ & Picotamide & Possibly not effective \\
\hline Triptans (MRM) & Triptans (MRM $\left.{ }^{b}\right)$ & Antiepileptic drugs & $\begin{array}{l}\text { Antidepressants } \\
\text { SSRI/SSNRI }\end{array}$ & Acebutolol $^{\mathrm{a}}$ \\
\hline \multirow[t]{16}{*}{ Frovatriptan ${ }^{\mathrm{b}}$} & Naratriptan ${ }^{\mathrm{b}}$ & & Fluvoxamine $^{\mathrm{a}}$ & Clonazepam \\
\hline & Zolmitriptan ${ }^{\mathrm{b}}$ & Carbamazepine $^{\mathrm{a}}$ & Fluoxetine & Nabumetone $^{\mathrm{a}}$ \\
\hline & & Beta blockers & Antiepileptic drugs & Oxcarbazepine \\
\hline & & Nebivolol & Gabapentin & Telmisartan \\
\hline & & Pindolol $^{a}$ & TCAs & \\
\hline & & Antihistamines & Protriptyline $^{a}$ & \\
\hline & & Cyproheptadine & Beta blockers & \\
\hline & & & Bisoprolol $^{a}$ & \\
\hline & & & Calcium blockers & \\
\hline & & & Nicardipine $^{a}$ & \\
\hline & & & Nifedipine ${ }^{a}$ & \\
\hline & & & Nimodipine & \\
\hline & & & Verapamil & \\
\hline & & & Direct vascular smooth & \\
\hline & & & muscle relaxants & \\
\hline & & & Cyclandelate & \\
\hline
\end{tabular}

Notes: a Classification based on original guideline and new evidence not found for this report; bfor short-term prophylaxis of MRM. (C2012. Wolters Kluwer Health. Reproduced with permission from Silberstein DS, Holland S, Freitag F, et al. ${ }^{30}$

Abbreviations: ACE, angiotensin-converting enzyme; MRM, menstrually related migraine; SSNRI, selective serotonin-norepinephrine reuptake inhibitor; SSRI, selective serotonin reuptake inhibitor; TCA, tricyclic antidepressant. 
Table 2 Classification of migraine preventive therapies (available in the US) of herbal preparations, minerals, vitamins, and others

\begin{tabular}{|c|c|c|c|c|}
\hline $\begin{array}{l}\text { Level A: medications } \\
\text { with established efficacy } \\
\text { (at least Class I trials) }\end{array}$ & $\begin{array}{l}\text { Level B: medications } \\
\text { are probably effective } \\
\text { (one Class I or at least } \\
\text { two Class II studies) }\end{array}$ & $\begin{array}{l}\text { Level C: medications } \\
\text { are possibly effective } \\
\text { (one Class II study) }\end{array}$ & $\begin{array}{l}\text { Level U: inadequate } \\
\text { or conflicting data } \\
\text { to support or refute } \\
\text { medication use }\end{array}$ & $\begin{array}{l}\text { Other: medications } \\
\text { that are established } \\
\text { as possibly or } \\
\text { probably ineffective }\end{array}$ \\
\hline $\begin{array}{l}\text { Herbal preparations, } \\
\text { vitamins, minerals, } \\
\text { and other }\end{array}$ & NSAIDs & NSAIDs & NSAIDs & Probably not effective \\
\hline \multirow[t]{11}{*}{ Petasites } & Fenoprofen ${ }^{a}$ & Flurbiprofen ${ }^{\mathrm{a}}$ & Aspirin & $\begin{array}{l}\text { Leukotriene receptor } \\
\text { antagonist }\end{array}$ \\
\hline & Ibuprofen $^{\mathrm{a}}$ & Mefenamic acid ${ }^{\mathrm{a}}$ & Indomethacin ${ }^{\mathrm{a}}$ & Montelukast \\
\hline & Ketoprofen ${ }^{a}$ & $\begin{array}{l}\text { Herbal preparations } \\
\text { vitamins, minerals, } \\
\text { and other }\end{array}$ & $\begin{array}{l}\text { Herbal preparations } \\
\text { vitamins, minerals, } \\
\text { and other }\end{array}$ & \\
\hline & Naproxen $^{a}$ & CoQI0 & Omega-3 & \\
\hline & Naproxen sodium ${ }^{a}$ & Estrogen & Other & \\
\hline & $\begin{array}{l}\text { Herbal preparations, } \\
\text { vitamins, minerals, } \\
\text { and other }\end{array}$ & Antihistamine & Hyperbaric oxygen & \\
\hline & Magnesium & Cyproheptadine & & \\
\hline & MIG-99 (feverfew) & & & \\
\hline & Riboflavin & & & \\
\hline & Histamines & & & \\
\hline & Histamine SC & & & \\
\hline
\end{tabular}

Note: andicates classification based on original guideline and new evidence not found for this report.

C2012. Wolters Kluwer Health. Reproduced with permission from Holland S, Silberstein SD, Freitag DW et al. ${ }^{31}$

Abbreviations: CoQ10, coenzyme QI0; NSAID, nonsteroidal anti-inflammatory drug; SC, subcutaneous.

intensity between both groups, ${ }^{33}$ yet patients on topiramate $50 \mathrm{mg} /$ day experienced a higher mean of reduction in all three aspects when compared to patients on propranolol $80 \mathrm{mg} /$ day (topiramate frequency decrease 4.23 versus propranolol 3.63; topiramate duration decrease 10.1 versus propranolol 7.83; topiramate intensity decrease 3.43 versus propranolol 2.3 ). In the study comparing topiramate $50 \mathrm{mg}$ /day and valproate $400 \mathrm{mg} /$ day, both groups had an overall reduction in headache frequency, duration, and intensity. ${ }^{37-40}$

Headache frequency decreased 1.8-fold with sodium valproate versus a three-fold reduction with topiramate, duration decreased by 13.4 hours with sodium valproate versus 11.9 hours with topiramate, and intensity decreased by 3.7 with sodium valproate versus 3.6 with topiramate from a baseline of 7.7 prior to treatment. There were several other Class II studies showing the efficacy of topiramate in migraine prevention. ${ }^{34-36,38-41}$ Four of these studies illustrated a significant efficacy when compared to placebo. . $^{35,36,40,41}$ Significant adverse effects of topiramate include paresthesias, memory and concentration problems, glaucoma, hyperchloremic acidosis, and nephrolithiasis.

\section{Divalproex}

There has been one double-blind, randomized Class I placebo-controlled study since the 2000 guidelines release.
In a 12-week trial, divalproex sodium (extended release dose of 500-1000 $\mathrm{mg} /$ day) resulted in a reduction in the 4-week migraine headache rate (3.2/week down from 4.4 /week in the active drug group and 3.6/week down from 4.2/week in the placebo group). ${ }^{42}$ Weight gain has been a problem with long-term use of divalproex sodium. ${ }^{42,43}$ Valproate can also cause drowsiness, hair thinning, alopecia, tremor, and gastrointestinal disturbance in addition to weight gain. More side effects include bone marrow dysfunction, pancreatitis, hepatitis, and kidney dysfunction. Valproate is also associated with teratogenicity and neural tube defects. In one study, $10 \%$ of women of childbearing age developed polycystic ovaries while on valproate for 1 year. ${ }^{44}$

\section{Gabapentin}

There has been one Class III study since the 2000 guidelines release. A median dose of $2400 \mathrm{mg} /$ day significantly reduced the monthly migraine rate when compared to placebo. ${ }^{20}$ This study was criticized as showing benefit in a completer analysis rather than in an intention-to-treat analysis, and follow-on trials have not been run.

\section{Lamotrigine}

There has been one study since the 2000 guidelines that failed to establish efficacy of lamotrigine in the prevention 
of migraine. When comparing lamotrigine $50 \mathrm{mg} /$ day to placebo and topiramate $50 \mathrm{mg} /$ day, lamotrigine was no more effective than placebo and less effective than topiramate in decreasing the frequency of migraine headaches. ${ }^{32}$ Among the adverse effects of lamotrigine are potentially life-threatening rash and gastrointestinal intolerance.

\section{Oxcarbazepine}

There has been one Class II trial comparing oxcarbazepine $1200 \mathrm{mg} /$ day to placebo that did not find any difference between the active drug and placebo in reducing the number of migraine headaches. ${ }^{45}$

\section{Antidepressants}

Venlafaxine is probably effective in migraine prevention and is also possibly as effective as amitriptyline. There is conflicting Class II evidence for fluoxetine. Amitriptyline is probably effective in migraine prevention and is probably as effective as topiramate and possibly as effective as venlafaxine in the prevention of migraines.

\section{$5 \mathrm{HT}$ reuptake inhibitors}

\section{Fluoxetine}

One Class II study had shown fluoxetine to be better than placebo for migraine prevention. ${ }^{46}$ No confirmatory study has been run, and overall the other fluoxetine studies have been either negative or equivocal.

\section{HT-norepinephrine reuptake inhibitors Venlafaxine}

As noted above, one Class I study reported a reduction in headache days at the dose of $150 \mathrm{mg} /$ day of venlafaxine. ${ }^{47}$ The noradrenergic effect of venlafaxine kicks in at $150 \mathrm{mg}$; the medication was ineffective at $75 \mathrm{mg}$ /day in this study. Adverse effects included nausea (41\%) and drowsiness (27\%). A second Class II comparative study demonstrated both venlafaxine and amitriptyline to be similarly effective in reducing headache frequencies. ${ }^{48}$ Adverse effects included nausea $(23 \%)$ in patients taking venlafaxine. Hypersomnolence (80\%) and dry mouth (69\%) were reported in patients taking amitriptyline.

\section{Tricyclic antidepressants}

In the 2012 guidelines, amitriptyline is no longer classified as a proven effective drug in migraine prevention. In comparison to venlafaxine ${ }^{48}$ and topiramate, ${ }^{38,39}$ amitriptyline was rated as having similar efficacy at doses tested.

\section{Antihypertensives: angiotensin-converting enzyme inhibitors and angiotensin receptor blockers}

There were no studies testing the efficacy of these medications in the 2000 guidelines. Since then, there have been three studies published. Lisinopril and candesartan are possibly effective in migraine prevention, each with a single small positive RCT. ${ }^{19,49}$ Telmisartan was ineffective in its RCT. ${ }^{50}$

\section{Angiotensin-converting enzyme inhibitors \\ Lisinopril}

One Class II RCT reported a reduction in three primary endpoints comparing lisinopril to placebo. ${ }^{48,49}$ These were headache days per month (19.7 versus 23.7), migraine days per month (14.5 versus 18.5), and headache hours (129 versus 162). There were no serious side effects. Other side effects included cough (26\%), dizziness (23\%), and fainting (10\%).

\section{Angiotensin receptor blockers Candesartan}

In one Class II crossover RCT conducted over a 12-week period, patients on candesartan reported 13.6 headache days per month compared to 18.5 days per month on placebo. ${ }^{19}$ Selected secondary endpoints showed an overall reduction of headache hours (139 versus 95), migraine days (12.6 versus 9.0), and headache severity index (293 versus 191). These were all statistically significant. The most common side effects reported were dizziness (41\%), muscular symptoms (21\%), and fatigue (14\%). These occurred at a rate similar to placebo.

\section{Telmisartan}

Only one Class II placebo-controlled study was conducted and showed no significant difference for this drug when compared to placebo. ${ }^{50}$ Why one angiotensin receptor blocker showed benefit (candesartan) and one did not (telmisartan) is unknown and certainly questions the notion of a class effect in migraine prevention for angiotensin receptor blockers.

\section{Beta blockers}

Propranolol and metoprolol are shown to be effective for migraine prevention. Propranolol is possibly as effective as cyproheptadine for prevention. Metoprolol is as effective as nebivolol or aspirin for migraine prevention.

\section{Metoprolol}

This drug has been reclassified as Class I in the 2012 guidelines. One new Class II trial showed metoprolol at $200 \mathrm{mg} /$ day 
attaining a 50\% migraine frequency reduction when compared to aspirin at $300 \mathrm{mg} /$ day. ${ }^{51} \mathrm{~A}$ second Class II study showed similar efficacy of metoprolol when compared to nebivolol in migraine prevention. ${ }^{52}$

\section{Propranolol}

Since the 2000 guidelines, in which propranolol was rated as effective for migraine prevention, another Class II study demonstrated that propranolol $(80 \mathrm{mg} /$ day $)$ was effective when compared to placebo and as effective as cyproheptadine. ${ }^{53}$ Reported side effects for propranolol included sleep disturbance, weight gain, and fatigue; however, the number of patients affected was not reported. As mentioned before in the topiramate section, propranolol was also found to be as effective as topiramate in one Class I study. ${ }^{33}$ Another Class II study also showed equivalent benefit between topiramate (100 and $200 \mathrm{mg} /$ day orally) and propranolol (160 mg/day orally). ${ }^{36}$

\section{Calcium channel blockers}

Both verapamil and nimodipine have been downgraded to Level $\mathrm{U}$ in the 2012 guidelines because of confounding data on these drugs. In the 2000 guidelines, both of these drugs were rated as probably effective for migraine prevention.

\section{Triptans}

Three triptans (frovatriptan, zolmitriptan, and naratriptan) are shown to be effective in the short-term prevention of menstrually related migraines (MRMs). Short-term prevention is not the same as daily prophylaxis. The paradigm involves starting the triptan several days before menstrual flow or the expected onset of MRM. The triptan is then given on a schedule for 5-6 days and then stopped. This approach is used to prevent the migraine occurring at menses only. Frovatriptan is effective in the short-term prevention of MRMs, while zolmitriptan and naratriptan are probably effective.

\section{Frovatriptan}

Two class I studies established efficacy of frovatriptan in the prevention of MRMs. ${ }^{54,55}$ In the first study, the headache frequency decreased after loading with frovatriptan and then administration of oral frovatriptan $2.5 \mathrm{mg}$ twice daily when compared to placebo. The number of headache-free perimenstrual periods was higher in two frovatriptan groups compared with placebo. In the second study, the incidence of MRM headaches during the 6-day perimenstrual period was lower in the group on oral frovatriptan $(2.5 \mathrm{mg}$ twice daily after a $10 \mathrm{mg}$ load) when compared to placebo. Adverse effects were similar between the frovatriptan group and placebo. ${ }^{56}$

\section{Naratriptan}

In one Class I study, the number of both migraine days and perimenstrual migraines were reduced. ${ }^{57}$ Patients receiving oral naratriptan $1 \mathrm{mg}$ twice daily (given for 5 days and commencing 2 days before menses onset) had 4.2 MRM days versus 7.0 for placebo. Adverse effects were similar to placebo.

\section{Zolmitriptan}

One Class I study established efficacy of zolmitriptan in patients when compared to placebo. ${ }^{58}$ Those receiving oral zolmitriptan $2.5 \mathrm{mg}$ twice daily or three times daily had an overall decrease in MRM frequency, but there was no advantage to the three times daily over the twice daily dosing regimen.

\section{OnabotulinumtoxinA}

OnabotulinumtoxinA is US Food and Drug Administration approved in prevention of chronic migraine (ie, headaches at least 15 days per month at least 4 hours per day). The 2012 guidelines were for episodic migraine (ie, headaches less than 15 days per month) and so do not cover onabotulinumtoxinA treatment, for which there is clearly Level A evidence of effectiveness. The guidelines were for a different diagnosis.

\section{NSAIDs and other complementary interventions for the prevention of migraines}

As noted above, the 2012 guidelines were published in two articles, with a new, second article that covered evidence on a miscellany of treatments. These included NSAIDs, injectable histamine desensitization, the antihistamine 5HT antagonist cyproheptadine, the leukotriene antagonist montelukast, hyperbaric oxygen, some estrogen and soy preparations, and herbs, minerals, vitamins, supplements, and complementary treatments in prevention of migraine, with categorizations on the level of evidence for each.

\section{Histamine/antihistamine/leukotriene receptor antagonists}

There were no studies for these interventions in the 2000 guidelines. Since then, several studies have been published to assess the efficacy of these compounds. Subcutaneous histamine is established to be probably 
effective for migraine prevention and possibly as effective as propranolol.

\section{Histamine}

There were two Class II RCTs published assessing the efficacy of subcutaneous histamine. ${ }^{56,59}$ The first study showed an overall reduction of headache frequency at 4 weeks when compared to placebo. ${ }^{59}$ The histamine group dropped from 3.8 to 0.5 compared to 2.9 from 3.6 in the placebo group. The compound tested was $\mathrm{N}$-alpha-methyl histamine (1-10 ng subcutaneous injections two times/week, with gradual escalation of dose). The only reported side effect was transient itching at the site of injection. A second Class II study showed histamine to be as effective as sodium valproate in reducing migraine attack frequency and better in reducing headache intensity and duration. ${ }^{56}$ Doses were $500 \mathrm{mg}$ /day for valproate and 1-2 $\mathrm{ng}$ twice weekly for subcutaneous histamine. No adverse effects were reported in the histamine groups. Adverse effects in the sodium valproate group included nausea, tremor, and weight gain.

\section{Cyproheptadine}

One Class II study found cyproheptadine ( $4 \mathrm{mg} /$ day) to be as effective as propranolol ( $80 \mathrm{mg} /$ day) in reducing migraine severity and frequency. ${ }^{53}$

\section{Montelukast}

In one Class I study, montelukast was shown to be no more effective than placebo in reducing monthly migraine attacks. ${ }^{60}$ There were no differences in adverse effects of significance.

\section{NSAIDs}

There were no additional studies since the 2000 guidelines assessing the efficacy of NSAIDs in the prevention of migraines, except for two studies on aspirin. The first study found aspirin to be as effective as metoprolol in the prevention of migraines. ${ }^{51}$ The second study found no difference in daily aspirin use combined with vitamin $\mathrm{E}$ versus placebo in combination with vitamin E. ${ }^{61}$ The efficacy of aspirin remains unknown. Daily NSAID use can result in $\mathrm{MOH} .{ }^{62}$ However, there is evidence that low frequency use of NSAIDs, at 1-4 days per month appears to be protective against development of $\mathrm{MOH}$, while use at 10-15 days per month appears to be provocative for development of MOH. ${ }^{13,63}$ Therefore, the use of daily NSAIDs in migraine prevention carries the risk of a paradoxical worsening of migraines, as well as risk for analgesic gastroenteropathy and nephropathy.

\section{Herbal preparation, vitamins, and minerals}

Since the 2000 guidelines, there have several studies assessing the efficacy of CoQ10, magnesium, MIG-99 (a purified feverfew parthenolide), estrogen, Petasites, riboflavin (vitamin B2), and hyperbaric oxygen. Petasites is established to be effective in migraine prevention. ${ }^{64,65}$ $\mathrm{CoQ} 10$ is possibly effective for migraine prevention, ${ }^{27}$ while riboflavin is probably effective. ${ }^{66}$ Percutaneous estradiol is possibly effective for migraine prevention, ${ }^{67}$ as is a combination of soy isoflavones (60 mg), dong quai (100 mg), and black cohosh $(50 \mathrm{mg}){ }^{67}$ Magnesium is also probably effective for migraine prevention, as seen in one additional study since the 2000 guidelines. ${ }^{68}$

MIG-99, a purified parthenolide preparation of feverfew, was ineffective or clinically insignificant in two RCTs. However, it received a rating of Level B in the 2012 guidelines. A more appropriate rating would have been Level U. ${ }^{69,70}$ Both hyperbaric oxygen ${ }^{66}$ and omega- $3^{71}$ showed unclear efficacy in the prevention of migraines.

\section{Canadian guidelines, 2012}

Guidelines for prevention of episodic migraine were also published in 2012 by the Canadian Headache Society. ${ }^{72}$ Conclusions on efficacy were similar, but the Canadian guidelines added a section on clinical impression of efficacy, as was done in the 2000 US Headache Consortium Guidelines, but not the US 2012 guidelines, which only listed the efficacy ratings.

The Canadian guidelines found strong strength of evidence for topiramate, propranolol, metoprolol, nadolol, and Petasites, as did the US 2012 guidelines. The Canadians differed from the 2012 US guidelines in finding strong strength of evidence for amitriptyline, riboflavin, and magnesium, which were Level B in the US 2012 guidelines. CoQ10 and magnesium were also rated with strong strength of evidence by the Canadians, but Level $\mathrm{C}$ in the US. Last was gabapentin, rated strong again by the Canadian guidelines but relegated to Level U in the 2012 US guidelines.

The clinical impression for the quality of both the evidence and effectiveness from the Canadian guidelines was high for topiramate, propranolol, metoprolol, and amitriptyline. Clinical impression was moderate quality for nadolol, gabapentin, candesartan, and Petasites. Finally, the consensus was low for riboflavin, CoQ10, and magnesium.

\section{Conclusion}

Daily migraine prevention remains a challenge to clinicians. When deciding on preventive treatment, a care provider should keep in mind the frequency, severity, and disability of migraines. The selection of a drug should be based upon 
level of evidence for efficacy, adverse effect profile, and patient comorbidities in order to treat multiple disorders at the time to improve adherence.

Drugs should be started at a low dose, raised to optimal dosage, and continued for a period of 2-3 months. Patients should keep headache diaries for progress to be assessed.

Various reasons play a role in the failure of treatment. These include unrealistic expectations of patient, poor drug adherence, and the overuse of abortive medication. ${ }^{73}$

Patients should therefore be educated about the utility of and limits for acute medication and the potential for development of $\mathrm{MOH}$. Appropriate prevention, by lowering frequency of headaches, should help prevent $\mathrm{MOH}$.

The set of guidelines published in 2012 give evidence for episodic migraine preventive therapies. Level A rating was given to valproate, topiramate, metoprolol, Petasites, propranolol, timolol, and - for short-term menstrual migraine prevention - frovatriptan.

OnabotulinumtoxinA is Food and Drug Administration approved for chronic migraine (ie, headaches at least 15 days per month at least 4 hours per day), a different diagnosis than was covered in the guidelines.

\section{Disclosure}

Dr Tepper receives grants/research support from Allergan, ATI, BristolMyerSquibb, GSK, MAP, Merck, NuPathe, Valkee, and Zogenix. These grants do not go to him personally, and do not count toward his salary at Cleveland Clinic. All amounts received are $<\$ 10,000 /$ year per Cleveland Clinic Policy and are listed on the Cleveland Clinic website. In the last 12 months he has served as a consultant for Allergan, ATI, MAP, Nautilus, NuPathe, Pfizer, and Zogenix; also in the last 12 months he has served on the Speakers Bureau for Allergan, MAP, Nautilus, and Zogenix, and served on Advisory Boards for Allergan, ATI, MAP, Nautilus, NuPathe, USWorldMeds, and Zogenix. He has stock options in ATI. Dr Estemalik reports no conflicts of interest in this work.

\section{References}

1. Headache Classification Subcommittee of the International Headache Society. The International Classification of Headache Disorders, 2nd ed. Cephalalgia. 2004;24(Suppl 1):9-160.

2. Stewart WF, Shechter A, Rasmussen BK. Migraine prevalence. A review of population-based studies. Neurology. 1994;44(6 Suppl 4): S17-S23.

3. Hu XH, Markson LE, Lipton RB, Stewart WF, Berger ML. Burden of migraine in the United States: disability and economic costs. Arch Intern Med. 1999;159(8):813-818.

4. Lipton RB, Bigal ME, Diamond M, Freitag F, Reed ML, Stewart WF. Migraine prevalence, disease burden, and the need for preventive therapy. Neurology. 2007;68(5):343-349.
5. Olesen J, Bousser MG, Diener HC, et al; Headache Classification Committee. New appendix criteria open for a broader concept of chronic migraine. Cephalalgia. 2006;26(6):742-746.

6. Gursoy-OzdemirY, Qiu J, Matsuoka N, et al. Cortical spreading depression activates and upregulates MMP-9. J Clin Invest. 2004;113(10): 1447-1455.

7. Leao AAP. Spreading depression of activity in the cerebral cortex. J Neurophysiol. 1944;7:359-390.

8. Busija DW, Bari F, Domoki F, Horiguchi T, Shimizu K. Mechanisms involved in the cerebrovascular dilator effects of cortical spreading depression. Prog Neurobiol. 2008;86(4):379-395.

9. Burstein R, Collins B, Jakubowski M. Defeating migraine pain with triptans: a race against the development of cutaneous allodynia. Ann Neurol. 2004;55(1):19-26.

10. Peroutka SJ. Developments in 5-hydroxytriptamine receptor pharmacology. In: Mathew NT, ed. Headache. neurologic clinics. Vol 8. Philadelphia, PA, USA: W. B. Saunders Company. 1990:829-830-839.

11. Silberstein SD, Goadsby PJ. Migraine: preventive treatment. Cephalalgia. 2002;22(7):491-512.

12. Silberstein SD, Lipton RB, Goadsby PJ. Headache in Clinical Practice, 2nd ed. London: Informa Healthcare; 2002. Chapter 16, page 92.

13. Bigal ME, Serrano D, Buse D, Scher A, Stewart WF, Lipton RB. Acute migraine medications and evolution from episodic to chronic migraine: a longitudinal population-based study. Headache. 2008; 48(8): 1157-1168.

14. Ayata C, Jin H, Kudo C, Dalkara T, Moskowitz MA. Suppression of cortical spreading depression in migraine prophylaxis. Ann Neurol. 2006;59(4):652-661.

15. Heninger FR, Charney DS. Mechanism of action of antidepressant treatments: implications for the etiology and treatment of depressive disorders. In: Meltzer HY, editor. Psychopharmacology: The Third Generation of Progress. New York, NY: Raven Press; 1987: 535-544.

16. Peroutka SJ. Developments in 5-hydroxytriptamine receptor pharmacology. In: Mathew NT, ed. Headache. neurologic clinics. Vol 8. Philadelphia, PA: W. B. Saunders Company. 1990:829-830-839.

17. Miljanich GP, Ramachandran J. Antagonists of neuronal calcium channels: structure, function, and therapeutic implications. Annu Rev Pharmacol Toxicol. 1995;35:707-734.

18. Ablad B, Dahlof C. Migraine and beta-blockade: modulation of sympathetic neurotransmission. Cephalalgia. 1986;6(Suppl 5):7-13.

19. Tronvik E, Stovner LJ, Helde G, Sand T, Bovim G. Prophylactic treatment of migraine with an angiotensin II receptor blocker: a randomized controlled trial. JAMA. 2003;289(1):65-69.

20. Mathew NT, Rapoport A, Saper J, et al. Efficacy of gabapentin in migraine prophylaxis. Headache. 2001;41(2):119-128.

21. Shank RP, Gardocki JF, Streeter AJ, Maryanoff BE. An overview of the preclinical aspects of topiramate: pharmacology, pharmacokinetics, and mechanism of action. Epilepsia. 2000;41(Suppl 1):S3-S9.

22. Cutrer FM, Limmroth V, Moskowitz MA. Possible mechanisms of valproate in migraine prophylaxis. Cephalalgia. 1997;17(2):93-100.

23. Moskowitz MA. Neurogenic versus vascular mechanisms of sumatriptan and ergot alkaloids in migraine. Trends Pharmacol Sci. 1992;13(8): 307-311.

24. Mauskop A, Altura BT, Cracco RQ, Altura BM. Deficiency in serum ionized magnesium but not total magnesium in patients with migraines. Possible role of ICa2+/IMg2+ ratio. Headache. 1993;33(3): 135-138.

25. Tepper SJ, Bigal M, Rapoport A, Sheftell F. Alternative therapies: evidence-based evaluation in migraine. Headache Care. 2006;3(2-3): $57-64$.

26. Sheftell F, Rapoport A, Weeks R, Walker B, Gammerman I, Baskin S. Montelukast in the prophylaxis of migraine: a potential role for leukotriene modifiers. Headache. 2000;40(2):158-163.

27. Sandor PS, Di Clemente L, Coppola G, et al. Efficacy of coenzyme Q10 in migraine prophylaxis: a randomized controlled trial. Neurology. 2005;64(4):713-715. 
28. Schoenen J, Jacquy J, Lenaerts M. Effectiveness of high-dose riboflavin in migraine prophylaxis. A randomized controlled trial. Neurology. 1998;50(2):466-470.

29. Silberstein SD. Practice parameter: evidence-based guidelines for migraine headache (an evidence-based review): report of the quality standards subcommittee of the American Academy of Neurology. Neurology. 2000;55(6):754-762.

30. Silberstein SD, Holland S, Freitag F, Dodick DW, Argoff C, Ashman E. Evidence-based guideline update: pharmacologic treatment for episodic migraine prevention in adults: report of the quality standards subcommittee of the American Academy of Neurology and the American Headache Society. Neurology. 2012;78(17): 1337-1345.

31. Holland S, Silberstein SD, Freitag F, Dodick DW, Argoff C, Ashman E. Evidence-based guideline update: NSAIDs and other complementary treatments for episodic migraine prevention in adults: report of the quality standards subcommittee of the American Academy of Neurology and the American Headache Society. Neurology. 2012;78(17): 1346-1353.

32. Gupta P, Singh S, Goyal V, Shukla G, Behari M. Low-dose topiramate versus lamotrigine in migraine prophylaxis (the Lotolamp study). Headache. 2007;47(3):402-412.

33. Ashtari F, Shaygannejad V, Akbari M. A double-blind, randomized trial of low-dose topiramate vs propranolol in migraine prophylaxis. Acta Neurol Scand. 2008;118(5):301-305.

34. Millan-Guerrero RO, Isais-Millan R, Barreto-Vizcaino S, et al. Subcutaneous histamine versus topiramate in migraine prophylaxis: a double-blind study. Eur Neurol. 2008;59(5):237-242.

35. Brandes JL, Saper JR, Diamond M, et al. Topiramate for migraine prevention: a randomized controlled trial. JAMA. 2004;291(8): 965-973.

36. Diener HC, Tfelt-Hansen P, Dahlof C, et al. Topiramate in migraine prophylaxis - results from a placebo-controlled trial with propranolol as an active control. $J$ Neurol. 2004;251(8):943-950.

37. Shaygannejad V, Janghorbani M, Ghorbani A, Ashtary F, Zakizade N, Nasr V. Comparison of the effect of topiramate and sodium valporate in migraine prevention: a randomized blinded crossover study. Headache. 2006;46(4):642-648

38. Dodick DW, Freitag F, Banks J, et al. Topiramate versus amitriptyline in migraine prevention: a 26-week, multicenter, randomized, double-blind, double-dummy, parallel-group noninferiority trial in adult migraineurs. Clin Ther. 2009;31(3):542-559.

39. Keskinbora K, Aydinli I. A double-blind randomized controlled trial of topiramate and amitriptyline either alone or in combination for the prevention of migraine. Clin Neurol Neurosurg. 2008;110(10): 979-984.

40. Mei D, Capuano A, Vollono C, et al. Topiramate in migraine prophylaxis: a randomised double-blind versus placebo study. Neurol Sci. 2004;25(5):245-250.

41. Silberstein SD, Neto W, Schmitt J, Jacobs D; MIGR-001 Study Group. Topiramate in migraine prevention: results of a large controlled trial. Arch Neurol. 2004;61(4):490-495.

42. Freitag FG, Collins SD, Carlson HA, et al. A randomized trial of divalproex sodium extended-release tablets in migraine prophylaxis. Neurology. 2002;58(11):1652-1659.

43. Silberstein SD, Collins SD. Safety of divalproex sodium in migraine prophylaxis: an open-label, long-term study. Headache. 1999;39(9): 633-643.

44. Joffe H, Cohen LS, Suppes T, et al. Valproate is associated with newonset oligoamenorrhea with hyperandrogenism in women with bipolar disorder. Biol Psychiatry. 2006;59(11):1078-1086.

45. Silberstein S, Saper J, Berenson F, Somogyi M, McCague K, D'Souza J. Oxcarbazepine in migraine headache: a double-blind randomized, placebo-controlled study. Neurology. 2008;70(7):548-555.

46. Saper JR, Silberstein SD, Lake AE 3rd, Winters ME. Double-blind trial of fluoxetine: chronic daily headache and migraine. Headache. 1994; 34(9):497-502.
47. Ozyalcin SN, Talu GK, Kiziltan E, Yucel B, Ertas M, Disci R. The efficacy and safety of venlafaxine in the prophylaxis of migraine. Headache. 2005;45(2):144-152.

48. Bulut S, Berilgen MS, Baran A, Tekatas A, Atmaca M, Mungen B. Venlafaxine versus amitriptyline in the prophylactic treatment of migraine: randomized, double-blind, crossover study. Clin Neurol Neurosurg. 2004;107(1):44-48.

49. Schrader H, Stovner LJ, Helde G, Sand T, Bovim G. Prophylactic treatment of migraine with angiotensin converting enzyme inhibitor (lisinopril): randomised, placebo controlled, crossover study. BMJ. 2001;322(7277):19-22.

50. Diener HC, Gendolla A, Feuersenger A, et al. Telmisartan in migraine prophylaxis: a randomized, placebo-controlled trial. Cephalalgia. 2009;29(9):921-927.

51. Diener HC, Hartung E, Chrubasik J, et al. A comparative study of oral acetylsalicyclic acid and metoprolol for the prophylactic treatment of migraine. A randomized, controlled, double-blind, parallel group phase III study. Cephalalgia. 2001;21(2):120-128.

52. Schellenberg R, Lichtenthal A, Wohling H, Graf C, Brixius K. Nebivolol and metoprolol for treating migraine: an advance on beta-blocker treatment? Headache. 2008;48(1):118-125.

53. Rao BS, Das DG, Taraknath VR, Sarma Y. A double blind controlled study of propranolol and cyproheptadine in migraine prophylaxis. Neurol India. 2000;48(3):223-226.

54. Silberstein SD, Elkind AH, Schreiber C, Keywood C. A randomized trial of frovatriptan for the intermittent prevention of menstrual migraine. Neurology. 2004;63(2):261-269.

55. Brandes JL, Poole A, Kallela M, et al. Short-term frovatriptan for the prevention of difficult-to-treat menstrual migraine attacks. Cephalalgia. 2009;29(11):1133-1148.

56. Millan-Guerrero RO, Isais-Millan R, Barreto-Vizcaino $\mathrm{S}$, et al. Subcutaneous histamine versus sodium valproate in migraine prophylaxis: a randomized, controlled, double-blind study. Eur $J$ Neurol. 2007;14(10):1079-1084.

57. Newman L, Mannix LK, Landy S, et al. Naratriptan as short-term prophylaxis of menstrually associated migraine: a randomized, doubleblind, placebo-controlled study. Headache. 2001;41(3):248-256.

58. Tuchman MM, Hee A, Emeribe U, Silberstein S. Oral zolmitriptan in the short-term prevention of menstrual migraine: a randomized, placebo-controlled study. CNS Drugs. 2008;22(10):877-886.

59. Millan-Guerrero RO, Isais-Millan R, Benjamin TH, Tene CE. $\mathrm{N}$-alpha-methyl histamine safety and efficacy in migraine prophylaxis: phase III study. Can J Neurol Sci. 2006;33(2):195-199.

60. Brandes JL, Visser WH, Farmer MV, et al. Montelukast for migraine prophylaxis: a randomized, double-blind, placebo-controlled study. Headache. 2004;44(6):581-586.

61. Bensenor IM, Cook NR, Lee IM, Chown MJ, Hennekens CH, Buring JE. Low-dose aspirin for migraine prophylaxis in women. Cephalalgia. 2001;21(3):175-183.

62. Silberstein SD, Olesen J, Bousser MG, et al. The International Classification of Headache Disorders, 2nd edition (ICHD-II) revision of criteria for 8.2 medication-overuse headache. Cephalalgia. 2005;25(6):460-465.

63. Bigal ME, Rapoport AM, Sheftell FD et al. Transformed migraine and medication overuse in a tertiary headache centre-clinical characteristics and treatment outcomes. Cephalalgia. 2004;24:483-490.

64. Grossman W, Schmidramsl H. An extract of Petasites hybridus is effective in the prophylaxis of migraine. Altern Med Rev. 2001;6(3):303-310.

65. Lipton RB, Gobel H, Einhaupl KM, Wilks K, Mauskop A. Petasites hybridus root (butterbur) is an effective preventive treatment for migraine. Neurology. 2004;63(12):2240-2244.

66. Eftedal OS, Lydersen S, Helde G, White L, Brubakk AO, Stovner LJ. A randomized, double blind study of the prophylactic effect of hyperbaric oxygen therapy on migraine. Cephalalgia. 2004;24(8):639-644.

67. MacGregor EA, Frith A, Ellis J, Aspinall L, Hackshaw A. Prevention of menstrual attacks of migraine: a double-blind placebo-controlled crossover study. Neurology. 2006;67(12):2159-2163. 
68. Maizels M, Blumenfeld A, Burchette R. A combination of riboflavin, magnesium, and feverfew for migraine prophylaxis: a randomized trial. Headache. 2004;44(9):885-890.

69. Pfaffenrath V, Diener HC, Fischer M, Friede M, Henneicke-von Zepelin HH. The efficacy and safety of Tanacetum parthenium (feverfew) in migraine prophylaxis - a double-blind, multicentre, randomized placebo-controlled dose-response study. Cephalalgia. 2002;22(7):523-532.

70. Diener HC, Pfaffenrath V, Schnitker J, Friede M, Henneicke-von Zepelin HH. Efficacy and safety of $6.25 \mathrm{mg}$ t.i.d. feverfew CO2-extract (MIG-99) in migraine prevention - a randomized, double-blind, multicentre, placebo-controlled study. Cephalalgia. 2005;25(11): 1031-1041.
71. Pradalier A, Bakouche P, Baudesson G, et al. Failure of omega-3 polyunsaturated fatty acids in prevention of migraine: a double-blind study versus placebo. Cephalalgia. 2001;21(8):818-822.

72. Pringsheim T, Davenport W, Mackie G, et al. Canadian Headache Society guideline for migraine prophylaxis. Can J Neurol Sci. 2012; 39(2 Suppl 2):S1-S59.

73. Lipton RB, Silberstein SD, Saper JR, Bigal ME, Goadsby PJ. Why headache treatment fails. Neurology. 2003;60(7):1064-1070.

\section{Publish your work in this journal}

Neuropsychiatric Disease and Treatment is an international, peerreviewed journal of clinical therapeutics and pharmacology focusing on concise rapid reporting of clinical or pre-clinical studies on a range of neuropsychiatric and neurological disorders. This journal is indexed on PubMed Central, the 'PsycINFO' database and CAS.
The manuscript management system is completely online and includes a very quick and fair peer-review system, which is all easy to use. Visit http://www.dovepress.com/testimonials.php to read real quotes from published authors.

Submit your manuscript here: http://www.dovepress.com/neuropsychiatric-disease-and-treatment-journal 